\title{
Role of Coxsackie B viruses in myocardial infarction
}

\author{
S. F. WOO D $, A . S . R O G E N, E . J . B E L L, A N D N, R$. G R I S T \\ From the Departments of Cardiology and General Medicine, Stobhill General Hospital, Glasgow, and the \\ Regional Virus Laboratory and Glasgow University Department of Infectious Diseases, Ruchill Hospital, \\ Glasgow
}

SUMMARY Serological evidence of Coxsackie B virus infection was found in 13.5 per cent of 52 patients with acute myocardial infarction and in 19 per cent of 52 controls with chest pain but normal electrocardiograms. In contrast to an Australian report, but in agreement with previous findings in Glasgow, it seems unlikely that Coxsackie B viruses contribute significantly to the causation of myocardial infarction.

The importance of enteroviruses, mainly those of the Coxsackie group, as causes of acute myocarditis and pericarditis is now well recognised and has been confirmed by studies in the West of Scotland (Bell and Grist, 1968; Dawson and Rogen, 1970; Grist and Bell, 1974). Though these investigations provided no proof that Coxsackie viruses were important causes of other types of heart disease it seemed worth exploring further their relation to the common and important problem of acute myocardial infarction. Damage or extra metabolic demands caused by virus infection might conceivably precipitate infarction in a myocardium with compromised circulation. In baby mice Coxsackie B3 virus infection can produce 'permanent myocardial injury' (Lerner and Wilson, 1973). The epidemiological shift of primary virus infections from childhood to later adult life might be reflected in rising incidence of virus-induced heart damage in adults (Grist and Bell, 1969) and would thus be a factor in the increase of myocardial infarction in recent years. During our investigations Australian workers reported that 8.6 per cent of their patients with acute myocardial infarction had evidence of Coxsackie B virus infection (Woods et al., 1975), but their study was not controlled. Our own investigation incorporated a control group of patients referred to the same clinic in whom myocardial infarction was not confirmed.

\section{Patients and methods}

Studies were made on 104 patients during Novem-

'Present address: 36 Cunningham Drive, Giffnock, Glasgow G46 6ER.

Received for publication 2 August 1977
Table 1 Age and sex of patients in study

\begin{tabular}{lll}
\hline & $\begin{array}{l}\text { Group 1 } \\
(52 \text { myocardial infarcts) }\end{array}$ & $\begin{array}{l}\text { Group 2 } \\
\text { (52 controls) }\end{array}$ \\
\hline Age range (years) & & \\
30 to 39 & $2(0)^{\star}$ & $10(3)$ \\
40 to 49 & $11(2)$ & $14(2)$ \\
50 to 59 & $11(4)$ & $21(4)$ \\
$60+$ & $28(1)$ & $7(1)$ \\
Mean age (years) & $58 \cdot 6$ & $49 \cdot 0$ \\
Virus positive patients & $54 \cdot 0$ & $48 \cdot 0$ \\
Virus negative patients & $59 \cdot 6$ & $49 \cdot 2$ \\
Male: female & $39: 13$ & $29: 23$ \\
Virus positive patients & $5: 2$ & $7: 3$ \\
Virus negative patients & $34: 11$ & $22: 20$ \\
\hline
\end{tabular}

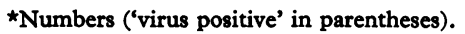

ber 1974 to May 1975, who were divided into two groups (Table 1).

Group 1 consisted of 52 patients with acute myocardial infarction admitted to the Coronary Care Unit of Stobhill General Hospital. The diagnosis was substantiated by the accepted electrocardiographic features of myocardial infarction and a serial rise of myocardial enzymes (aspartate aminotransferase, alanine aminotransferase, lactic dehydrogenase), in addition to the clinical presentation.

Group 2 consisted of 52 patients referred to the out-patient electrocardiographic clinic by their family doctors after complaining of chest pain. This service has operated since 1967, and is described elsewhere (Dawson, 1969). Additional criteria for inclusion in this group were that the electrocardiogram should be normal as reported by one of us (A.S.R.) and that the patients should be considered likely to co-operate in the study as assessed by S.F.W., the purposes of the study having been explained to them. It was appreciated 
that a normal electrocardiogram did not preclude the possibility of ischaemic heart disease, but since the start of the out-patient electrocardiograph service family doctors had been occasionally reminded that the service was designed for patients in whom heart disease was not suspected on clinical grounds and referral for an electrocardiogram was primarily to confirm such a clinical impression. It was further pointed out to the family doctor that if there was suspicion of heart disease patients should be dealt with through the existing channels, e.g. by direct admission to hospital, to the outpatient department, or by domiciliary consultation. In this way there was screening at family doctor level, and, in addition, S.F.W. had the benefit of further interview with the 35 patients who returned for second blood withdrawal.

Blood samples were withdrawn from Group 1 patients initially in the coronary care unit and 10 to 14 days later from 38 patients while recovering in a general medical ward. Patients in Group 2 hadblood taken at their attendance at the out-patient electrocardiographic clinic and 10 to 14 days later from 35 who returned to help with the study. Sera were tested for neutralising antibodies to the 6 types of Coxsackie B virus by a micro-metabolic inhibition test (Bell and Grist, 1970). On the basis of previous experience with this test (Grist and Bell, 1974) patients were classified as showing evidence of Coxsackie virus infection if the antibody titre to any of the Coxsackie virus types was 256 or more (in only one patient (Group 2) were significant rising antibody titres detected). Single specimens only were available for study from some patients in both groups.

\section{Results}

Of the 52 patients in Group 1, 7 showed evidence of recent infection with a Coxsackie virus (13.5\%) compared with 10 of the 52 patients in Group 2 $(19 \%)$. Table 1 shows no relation between mean age and frequency of infection, though the mean age of Group 2 was about 9 years less than that of Group 1. However, the male predominance in Group 1 is reflected only in those patients of Group 2 who showed evidence of infection. Group 1 was subsequently divided into anterior and inferior infarcts: in the 7 patients with evidence of infection all infarcts were anterior, whereas $19(42 \%)$ were inferior in those with no evidence of viral infection. Table 2 shows the antibodies to individual Coxsackie viruses in both groups. Table 3 gives the monthly distribution of patients investigated, by date of initial specimen collection. It also shows those whose antibody titres suggested recent or
Table 2 Types of virus involved *

\begin{tabular}{llllllll}
\hline & \multicolumn{1}{c}{ Coxsackie virus } & & \\
& $B 1$ & $B 2$ & $B 3$ & $B 4$ & $B 5$ & $B 6$ & $B 1,3,4,5$ \\
\hline Group 1 & 1 & 0 & 2 & 4 & 0 & 0 & 0 \\
Group 2 & 0 & 1 & 3 & 5 & 0 & 0 & $1+$ \\
\hline
\end{tabular}

^Highest ( $>256$ ) neutralising antibody titre detected. tGreater than fourfold rising titres to all these viruses.

Table 3 Monthly distribution of patients tested and those with evidence of Coxsackie $B$ infections

\begin{tabular}{lrrrrrrrr}
\hline & 1974 & \multicolumn{7}{c}{1975} \\
& Nov & Dec & Fan & Feb & Mar & Apr & May \\
\hline Group 1: & No. tested & 4 & 10 & 5 & 0 & 12 & 11 & 10 \\
No. positive & 2 & 4 & 0 & 0 & 1 & 0 & 0 \\
Group 2: & No. tested & 10 & 2 & 7 & 7 & 26 & 0 & 0 \\
No. positive & 1 & 0 & 0 & 0 & 9 & 0 & 0 \\
\hline
\end{tabular}

current Coxsackie B infection: 10/52 (19\%) of controls (samples over 5 months) as compared with the myocardial infarct group $(7 / 52(13.5 \%)$ over 7 months; $7 / 31(22.6 \%)$ samples over the same 5 month period as the controls).

\section{Discussion}

Our study suggested that there was no increased incidence of Coxsackie $B$ infection in patients with acute myocardial infarction, in contrast with the report from Fremantle, W. Australia. However, the use of patients with chest pain as a control group might have biased the study against proving an association between myocardial infarction and Coxsackie virus disease, since some positive virological findings in Group 2 might represent cases of Bornholm disease. In evaluating the significance of the percentages of patients whose antibody titres were above the level suggesting recent infection (i.e. 256 or more) it should be remembered that this is not an absolute threshold but one which distinguishes reasonably between high and low probabilities. The number of persons 'positive' at this level in other local populations being studied by one of us (E.J.B., unpublished) ranges from 1 to 20 per cent, averaging about 10 per cent which is in agreement with previous findings (Grist and Bell, 1974). It was interesting to note the 100 per cent predominance of anterior infarction in the 7 patients with both acute myocardial infarction and evidence of Coxsackie viral infection, whereas the Australian workers reported 60 per cent of anterior infarction in their 20 patients with Coxsackie viral infection (Woods et al., 1975).

We also realise that our study was subject to seasonal fluctuation in enterovirus infection since it did not cover the complete year, but extended 
investigations seemed unjustified since the findings agreed with previous failure to find a higher frequency of enterovirus infections over a 6-year period in patients with acute myocardial infarction than in those with non-cardiac diseases initially suspected of being cardiac (Grist and Bell, 1974). Though Coxsackie viruses may perhaps occasionally precipitate myocardial infarction, it seems unlikely that they do so to any important extent, at any rate in Western Scotland.

We thank the physicians of Stobhill General Hospital who gave us permission to study patients in their care and the National Fund for Research into Crippling Diseases for providing financial support for the laboratory tests.

\section{References}

Bell, E. J., and Grist, N. R. (1968). Coxsackievirus infections in patients with acute cardiac disease and chest pain.
Scottish Medical fournal, 13, 47-51.

Bell, E. J., and Grist, N. R. (1970). Further studies of enterovirus infections in cardiac disease and pleurodynia. Scandinavian Fournal of Infectious Diseases, 2, 1-6.

Dawson, K. P. (1969). A general practitioner electrocardiograph service. Practitioner, 203, 70-72.

Dawson, K. P., and Rogen, A. S. (1970). Cardiac complications of Coxsackie virus group B infection. Practitioner, 205, 333-335.

Grist, N. R., and Bell, E. J. (1969). Coxsackie viruses and the heart. American Heart fournal, 77, 295-300.

Grist, N. R., and Bell, E. J. (1974). A six-year study of Coxsackievirus B infections in heart disease. fournal of Hygiene, 73, 165-172.

Lerner, A. M., and Wilson, F. M. (1973). Virus myocardiopathy. Progress in Medical Virology, 15, 63-91.

Woods, J. D., Nimmo, M. J., and MacKay-Scollay, E. M. (1975). Acute transmural myocardial infarction associated with active Coxsackie B infection. American Heart fournal, 89, 283-287.

Requests for reprints to Professor N. R. Grist, Regional Virus Laboratory, Ruchill Hospital, Glasgow G20 9NB. 